\title{
Investigation of Deposition Conditions of Thin Copper Films from Electrode Destruction Products of Overvoltage High-voltage Discharge in High Pressure Argon
}

\author{
O.K. Shuaibovi,,* O.Y. Mynia ${ }^{1}$, V.I. Chyhin², R.V. Hrytsak ${ }^{1}$, A.O. Malinina ${ }^{1}$, M.I. Vatrala ${ }^{1}$, Z.T. Homoki ${ }^{1}$ \\ 1 Uzhhorod National University, 3, Narodna Sq., 88000 Uzhhorod, Ukraine \\ 2 Lviv Polytechnic National University, 12, Bandera St., 79013 Lviv, Ukraine
}

(Received 16 April 2021; revised manuscript received 20 October 2021; published online 25 October 2021)

\begin{abstract}
The characteristics of a high-voltage nanosecond discharge between copper electrodes in argon at pressures of $100-150 \mathrm{kPa}$ are given. In the process of microexplosions of inhomogeneities on the working surfaces of electrodes in a strong electric field, copper vapors were introduced into the discharge gap due to the formation of ectons. This created the preconditions for the synthesis of thin nanostructured copper films of ultrafine copper powder. Copper films were deposited on a dielectric substrate installed near the electrode system. The spatial and electrical characteristics of high-voltage nanosecond discharge at a distance between the electrodes $d=2 \mathrm{~mm}$ were studied. The study of radiation spectra of discharge and oscillograms of radiation of the most intense spectral lines and bands was carried out, which allowed to establish the main excited products formed in plasma. The results of optimization of the intensity of UV radiation of discharge depending on the frequency, magnitude of the charging voltage and interelectrode distance are presented. The time-averaged UV radiation of the point emitter was optimized depending on the supply voltage of the high-voltage modulator and the frequency of discharge pulses. The light transmission spectra of thin copper films synthesized in the experiment were studied.
\end{abstract}

Keywords: High-voltage nanosecond discharge, Copper, Plasma, UV radiation.

DOI: 10.21272/jnep.13(5).05003

PACS numbers: 52.80. - s, 51.50. + v, 52.80.Tn, $52.90 .+\mathrm{z}, 52.80 . \mathrm{Mg}, 79.60 . \mathrm{Jv}$

\section{INTRODUCTION}

In an overvoltage nanosecond discharge in atmospheric pressure gases, the formation of ectons from the working surfaces of the electrodes is accompanied by the emission of steam from the electrode material into the interelectrode space [1]. When using electrodes made of transition metals, the synthesis of thin nanostructured films was performed [2-4] and ultrafine metal powders were obtained in sufficient quantities [5] for use in various nanotechnologies $[6,7]$.

The problem of accurate determination of the qualitative and quantitative composition of various samples by emission spectroscopy and synthesis of thin nanostructured high-purity metal films is closely related to the problem of obtaining pure plasma in gasdischarge sources with an open cycle. Thus, the authors [8] proposed the use of xenon instead of argon in the arc discharge. Since copper electrodes with water cooling were used in the plasmatron, groups of spectral lines of copper atoms $510.5,515.3$ and $521.8 \mathrm{~nm}$ in the wavelength ranges $210-231 \mathrm{~nm}$ and $224.7-327.3 \mathrm{~nm}$ were registered in the plasma emission spectra. The concentration of copper vapor in the plasma based on xenon increased significantly compared with the use of argon as a buffer gas, which led to an increase in the radiation intensity of spectral lines of copper atoms.

The results of modeling the parameters of the plasma per nanosecond discharge in argon of atmospheric pressure are given in [9]. Calculations have shown that the formation of the discharge begins with cathodedirected wave motion at a speed of $\approx 2.5 \cdot 10^{7} \mathrm{~cm} / \mathrm{s}$, and the concentration of electrons in the plasma after reaching time $t=40 \mathrm{~ns}$, except for the cathode layer, is in the range of $10^{13}-10^{14} \mathrm{~cm}^{-3}$ at an electric field strength of $\approx 10^{5} \mathrm{~V} / \mathrm{cm}$. However, in this work, there is no information about the possibility of synthesizing nanoparticles from the electrode material, and the discharge ignition mode was suboptimal for the efficient formation of ectons.

Studies of the conditions for the synthesis of thin copper films from the destruction products of copper electrodes in a high-voltage nanosecond discharge were practically not performed. Therefore, it is important to establish the deposition conditions and characteristics of films based on transition metals $(\mathrm{Cu}, \mathrm{Zn}, \mathrm{Cd}, \mathrm{Fe})$ in inert gases, which is carried out without the use of expensive laser or high-vacuum equipment.

The article presents the results of the study of spatial, electrical and optical characteristics of a highvoltage, overvoltage discharge of short duration in high pressure argon with small impurities of copper vapor introduced into the plasma due to the formation of ectons on the working surfaces of copper electrodes and light transmission by synthesized copper films.

\section{TECHNIQUE AND CONDITIONS OF THE EXPERIMENT}

The study of the characteristics of an overvoltage nanosecond discharge was performed in the discharge module, the scheme of which is given in [2,3]. The detected nanosecond discharge between the copper electrodes was ignited in a sealed plexiglass chamber. The distance between the copper electrodes was $d=2$ or $7 \mathrm{~mm}$.

The experimental setup contained a discharge module powered by a pulsed-periodic high-voltage source, a

*alexsander.shuaibov@uzhnu.edu.ua 
system for recording optical radiation based on a monochromator MDR-2 and a system for recording pulsed electrical and optical characteristics (current, voltage and oscillograms of the most intense spectral lines and bands) in time based on a multi-channel broadband oscilloscope 6-ENT.

To ignite the discharge, high-voltage bipolar pulses with a duration of $50-100 \mathrm{~ns}$ with an amplitude of $\pm(20-40) \mathrm{kV}$ were applied to the electrodes of the discharge cell. The repetition frequency of voltage pulses was chosen in the range of $80-100 \mathrm{~Hz}$, because at higher frequencies there was a significant heating of the discharge module. Oscillograms of voltage pulses on the bit gap and oscillograms of current pulses were recorded using a broadband capacitive voltage divider, Rogovsky belt and a broadband oscilloscope 6LOR-04.

A uniform discharge of about 100-150 ns with a pulse amplitude of 50-200 A and a plasma volume of $10-500 \mathrm{~mm}^{3}$ was ignited between the tips of the copper electrodes. The discharge interval was overvoltage, which created favorable conditions for the formation of a beam of divergent electrons of high energy and concomitant X-rays [10].

Plasma radiation, recorded in the spectral range $\lambda=196-663 \mathrm{~nm}$, was fed to the input slit of the spectrometer with a diffraction grating of $1200 \mathrm{bar} / \mathrm{mm}$. At the output of the spectrometer, a photoelectronic multiplier FEP-106 connected to a DC amplifier was used to detect radiation. A signal from the sub-amplifier was fed to an analog-to-digital converter and then to a personal computer for processing.

Measurement of the radiation power of the discharge plasma was performed using an ultraviolet meter of absolute radiation power "TKA-PKM", which allowed measurements in the spectral range of 200$400 \mathrm{~nm}$.

The study of light transmission (absorption) spectra by sprayed film structures was performed using an Ocean Optics USB2000 spectrometer and software was processed on a PC taking into account the absorption of radiation by a glass substrate. The surface image of thin nanostructured films was recorded using a CrossBeam Workstation Auriga scanning electron microscope (Carl Zeis).

The structure of the bit module is described in $[2,3]$. The discharge chamber was evacuated with a prevacuum pump to a residual pressure of $10 \mathrm{~Pa}$, and then argon was injected into the chamber to a pressure of 100 or $150 \mathrm{kPa}$. The diameter of cylindrical copper electrodes was $5 \mathrm{~mm}$, and the radius of curvature of their working end surface was the same and equal to $3 \mathrm{~mm}$.

The amount of discharge depended on the frequency of voltage pulses. The "point discharge" mode was achieved only at the repetition frequency of voltage pulses in the range $f=40-150 \mathrm{~Hz}$.

\section{SPATIAL AND ELECTRICAL CHARACTERISTICS}

Fig. 1 shows time-averaged images of a high-voltage nanosecond discharge at pressures $p(\mathrm{Ar})=100$ and $150 \mathrm{kPa}$ and the distance between the electrodes $d=2 \mathrm{~mm}$, which were obtained with camera time exposure of about $1 \mathrm{~s}$.

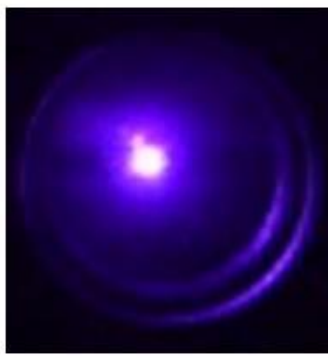

a

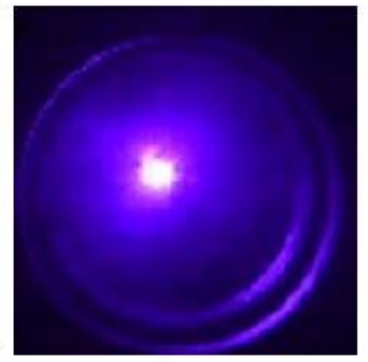

b
Fig. 1 - Photographs of a high-voltage nanosecond discharge between copper electrodes in argon at different pressures: 100 (a) and 150 (b) $\mathrm{kPa}$ and for the distance between the electrodes $d=2 \mathrm{~mm}$

At an argon pressure of $100 \mathrm{kPa}$, the high-wavelength nanosecond discharge had the appearance of a bright central spot with a diameter of about $4-5 \mathrm{~mm}$, which exceeded the interelectrode distance, from which green plasma jets flowed. As the argon pressure increased to $150 \mathrm{kPa}$, the diameter of the bright central part and the halo around it increased slightly.
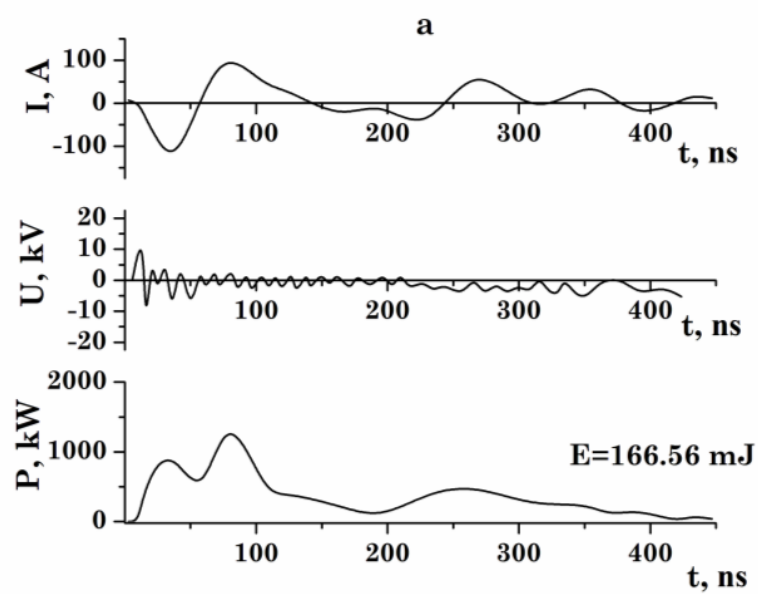

b
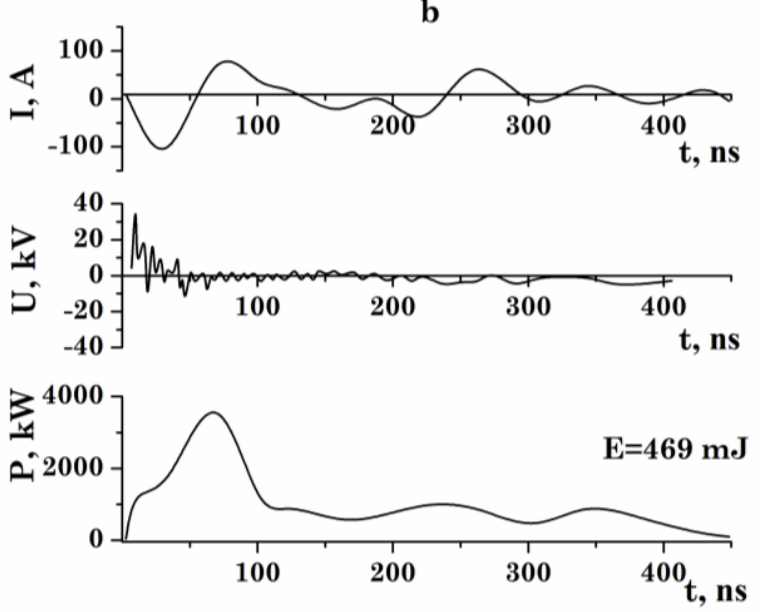

Fig. 2 - Time dependences of the pulsed electric power of the discharge, the voltage between copper electrodes and the current of the nanosecond discharge at the interelectrode distance $d=2 \mathrm{~mm}$ and $p(\mathrm{Ar})=100$ (a) and $150(\mathrm{~b}) \mathrm{kPa}$

Fig. 2 shows oscillograms of voltage, current and pulse power for a high-voltage nanosecond discharge 
between copper electrodes in high pressure argon at the distance between the electrodes $d=2 \mathrm{~mm}$.

Voltage and current oscillograms had the form of time-damped oscillations due to the mismatch of the output resistance of the high-voltage modulator with the load resistance. The total duration of the voltage oscillations on the gap and the discharge current reached $450 \mathrm{~ns}$ with the duration of individual voltage oscillations of 7-10 ns, and current oscillations had a duration of $\approx 70 \mathrm{~ns}$ (Fig. 2a). Short-term oscillations were best shown on voltage oscillograms. On current oscillograms, they were partially integrated over time due to the large time constant of Rogovsky belt used in these studies.

For a discharge in argon of atmospheric pressure at $d=2 \mathrm{~mm}$, the amplitude of the largest voltage drop on the electrodes was reached at the initial stage of the discharge and was $\approx \pm 7-8 \mathrm{kV}$, current $\pm 100 \mathrm{~A}$, and pulse power 1.2 MW, which provided the energy contribution of one discharge pulse to the plasma of about $167 \mathrm{~mJ}$ (Fig. 2a).

When the argon pressure increased to $150 \mathrm{kPa}$ (Fig. 2b), the voltage drop of different polarity in the initial phase of the discharge at $\tau=10-30 \mathrm{~ns}$ reached $40 \mathrm{kV}$, and the current was $\pm 80-100 \mathrm{~A}$. The maximum value of the electric pulse power reached $3.8 \mathrm{MW}$ at $t=70-80 \mathrm{~ns}$. The main energy contribution to the plasma was made during the first $100 \mathrm{~ns}$ from the moment of discharge ignition. The energy of one discharge pulse reached $\approx 470 \mathrm{~mJ}$ (Fig. $2 \mathrm{~b}$ ).

\section{OPTICAL CHARACTERISTICS}

Fig. 3 shows the emission spectra of a high-voltage nanosecond discharge between copper electrodes, which ignited at $p(\mathrm{Ar})=101 \mathrm{kPa}$ and the distance between the electrodes of $2 \mathrm{~mm}$, and the results of its interpretation are summarized in Table 1. Reference books were used in the identification of spectral lines in the spectra $[11,12]$.

The peculiarity of these radiation spectra was the presence of a continuum, against the background of which all spectral lines and bands were observed. The nature of this continuum in the conditions of our experiment is related to thermal and recombination plasma radiation. The shape of the continuum with a wide maximum at $400-450 \mathrm{~nm}$ correlates well with the results known from the literature. Thus, in [7, 8] for a spark discharge in argon at atmospheric pressure between aluminum electrodes at $d=10 \mathrm{~mm}$, an intense continuum was recorded in the radiation spectrum in the wavelength range $350-460 \mathrm{~nm}$ with a maximum at $\lambda=420 \mathrm{~nm}$.

The continuous spectrum of plasma radiation began to be recorded after a time interval $\Delta t=40 \mathrm{~ns}$ from the beginning of the discharge, when the intensity of argon ion lines began to increase sharply. The maximum intensity of the spectral lines ArII of the continuous spectrum was reached after a period of time $\Delta t=300-400 \mathrm{~ns}$ from the beginning of a sharp increase in the current [8].

At the stage of slow expansion of the spark channel, starting from the moment of time $500 \mathrm{~ns}$, the intensity of the continuum decreased, as well as the intensity of ionic spectral lines of argon, and the intensity of atomic lines (394.9, $308.2 \mathrm{~nm} \mathrm{ArI)} \mathrm{and} \mathrm{electrode} \mathrm{material} \mathrm{lines}$ (281.6, $289.1 \mathrm{~nm}$ AlII) increased [8].

In the radiation spectra of the discharge plasma (Fig. 3) in a mixture of argon and copper vapors in the UV wavelength range of 214-330 nm (lines 1-23, Table 1 ), radiation was observed at the transitions of an atom and a single-charged copper ion. The most intense ionic spectral line was the line with $\lambda=227.62 \mathrm{~nm}$.
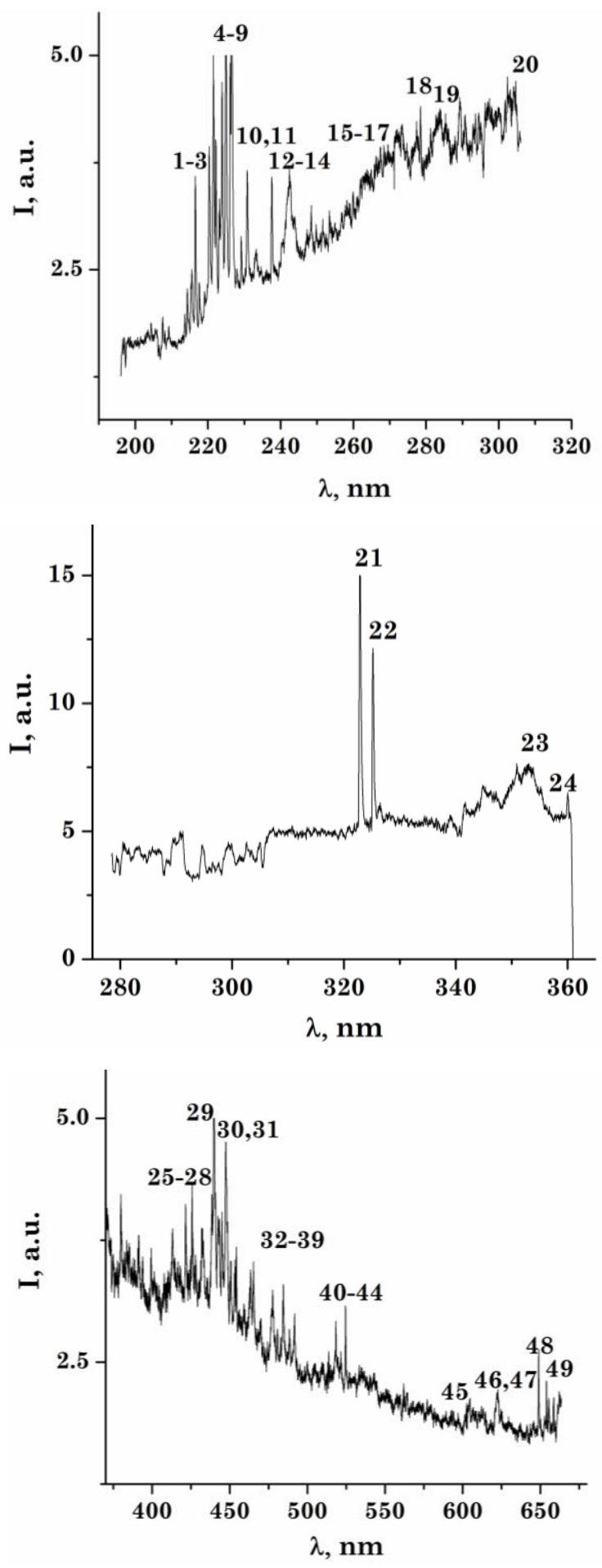

Fig. 3 - Radiation spectra of a high-voltage nanosecond discharge in argon between copper electrodes at $d=2 \mathrm{~mm}$ and $p(\mathrm{Ar})=150 \mathrm{kPa}$ 
Table 1 - The results of decoding the spectra of plasma radiation of a high-voltage nanosecond discharge between copper electrodes at $p(\mathrm{Ar})=150 \mathrm{kPa}$ and $d=2 \mathrm{~mm}$

\begin{tabular}{|c|c|c|c|c|c|c|c|}
\hline № & $\lambda, \mathrm{nm}$ & $I_{\text {exp, a.u. }}$ & Object & $E_{\text {low }}, \mathrm{eV}$ & $E_{\text {up }}, \mathrm{eV}$ & Lower term & Upper term \\
\hline 1 & 214.89 & 2.27 & $\mathrm{Cu}$ II & 1.39 & 7.18 & $4 \mathrm{~s}^{2}{ }^{2} \mathrm{D}$ & $5 \mathrm{f}^{2} \mathrm{~F}$ \\
\hline 2 & 216.50 & 2.50 & $\mathrm{Cu} \mathrm{I}$ & 0.00 & 5.72 & $4 \mathrm{~s}^{2} \mathrm{~S}$ & $4 p^{\prime 2} D$ \\
\hline 3 & 217.49 & 3.59 & $\mathrm{Cu} \mathrm{II}$ & 8.92 & 14.61 & $4 p^{1} F$ & $4 d^{1} G$ \\
\hline 4 & 220.05 & 3.92 & $\mathrm{Cu}$ II & 9.06 & 14.70 & $4 p^{3} D$ & $4 d^{3} \mathrm{~F}$ \\
\hline 5 & 221.45 & 5.03 & $\mathrm{Cu} \mathrm{I}$ & 1.39 & 6.98 & $4 s^{2} 2 \mathrm{D}$ & $4 p^{\prime \prime}{ }^{2} \mathrm{P}$ \\
\hline 6 & 223.84 & 3.32 & $\mathrm{Cu} \mathrm{I}$ & 1.64 & 7.18 & $4 s^{22} \mathrm{D}$ & $5 f^{2} F$ \\
\hline 7 & 224.70 & 4.69 & $\mathrm{Cu}$ II & 2.72 & 8.23 & $4 \mathrm{~s}^{3} \mathrm{D}$ & $4 p^{3} \mathrm{P}$ \\
\hline 8 & 226.30 & 5.04 & $\mathrm{Cu} \mathrm{I}$ & 1.64 & 7.12 & $4 s^{22} \mathrm{D}$ & $7 p^{2} P$ \\
\hline 9 & 227.62 & 5.05 & $\mathrm{Cu}$ II & 2.98 & 8.42 & $4 \mathrm{~s}^{3} \mathrm{D}$ & $4 p^{3} \mathrm{P}$ \\
\hline 10 & 229.43 & 2.88 & $\mathrm{Cu}$ II & 2.83 & 8.23 & $4 \mathrm{~s}^{3} \mathrm{D}$ & $4 p^{3} \mathrm{P}$ \\
\hline 11 & 230.31 & 3.65 & $\mathrm{Cu} \mathrm{I}$ & 1.64 & 7.02 & $4 s^{22} \mathrm{D}$ & $4 p^{\prime \prime}{ }^{2} \mathrm{D}$ \\
\hline 12 & 236.98 & 3.58 & $\mathrm{Cu}$ II & 3.26 & 8.49 & $4 \mathrm{~s}^{1} \mathrm{D}$ & $4 p^{3} F$ \\
\hline 13 & 239.26 & 2.57 & $\mathrm{Cu} \mathrm{I}$ & 1.64 & 6.82 & $4 s^{22} \mathrm{D}$ & $6 p^{2} \mathrm{P}$ \\
\hline 14 & 244.16 & 3.67 & $\mathrm{Cu} \mathrm{I}$ & 0.00 & 5.08 & $4 \mathrm{~s}^{2} \mathrm{~S}$ & $4 p^{\prime}{ }^{4} \mathrm{P}$ \\
\hline 15 & 249.21 & 3.25 & $\mathrm{Cu} \mathrm{I}$ & 0.00 & 4.97 & $4 \mathrm{~s}^{2} \mathrm{~S}$ & $4 p^{\prime}{ }^{4} \mathrm{P}$ \\
\hline 16 & 254.48 & 3.21 & $\mathrm{Cu}$ II & 8.52 & 13.39 & $4 p^{3} F$ & $5 s^{3} D$ \\
\hline 17 & 261.83 & 3.57 & $\mathrm{Cu} \mathrm{I}$ & 1.39 & 6.12 & $4 s^{2}{ }^{2} \mathrm{D}$ & $5 p^{2} \mathrm{P}$ \\
\hline 18 & 279.17 & 4.4 & $\mathrm{Cu}$ II & 14.33 & 18.77 & $4 d^{3} G$ & $6 f^{3} \mathrm{H}$ \\
\hline 19 & 282.43 & 4.3 & $\mathrm{Cu} \mathrm{I}$ & 1.39 & 5.78 & $4 s^{2}{ }^{2} \mathrm{D}$ & $4 p^{\prime 2} D$ \\
\hline 20 & 306.34 & 4.72 & $\mathrm{Cu} \mathrm{I}$ & 1.64 & 5.68 & $4 \mathrm{~s}^{2}{ }^{2} \mathrm{D}$ & $4 p^{\prime 2} \mathrm{P}$ \\
\hline 21 & 324.75 & 14.89 & $\mathrm{Cu} \mathrm{I}$ & 0 & 3.82 & $4 \mathrm{~s}^{2} \mathrm{~S}$ & $4 p^{2} \mathrm{P}$ \\
\hline 22 & 327.39 & 12.08 & $\mathrm{Cu} \mathrm{I}$ & 0 & 3.39 & $4 \mathrm{~s}^{2} \mathrm{~S}$ & $4 p^{2} \mathrm{P}$ \\
\hline 23 & 350.05 & 6.76 & $\mathrm{~N}_{2}$ & \multicolumn{4}{|c|}{ Second positive system $\mathrm{C}^{3} \Pi_{\mathrm{u}^{+}-\mathrm{B}^{3} \Pi_{\mathrm{g}}{ }^{+}(2 ; 3)}$} \\
\hline 24 & 357.69 & 7.64 & $\mathrm{~N}_{2}$ & \multicolumn{4}{|c|}{ Second positive system $\mathrm{C}^{3} \Pi_{\mathrm{u}}{ }^{-}-\mathrm{B}^{3} \Pi_{\mathrm{g}}{ }^{+}(0 ; 1)$} \\
\hline 25 & 420.06 & 4.11 & Ar I & 11.55 & 14.50 & $4 \mathrm{~s}[1 / 2]$ & $5 p[2 \quad 1 / 2]$ \\
\hline 26 & 425.93 & 4.32 & $\operatorname{ArI}$ & 11.83 & 14.74 & $4 s^{\prime}[1 / 2]$ & $5 p^{\prime}[1 / 2]$ \\
\hline 27 & 430.01 & 3.89 & Ar I & 11.62 & 14.51 & $4 \mathrm{~s}\left[1 \frac{1}{2}\right]$ & $5 p\left[11 \frac{1}{2}\right]$ \\
\hline 28 & 433.35 & 3.36 & Ar I & 11.83 & 14.69 & $4 s^{\prime}[1 / 2]$ & $5 p^{\prime}\left[1 \frac{1}{1}\right]$ \\
\hline 29 & 440.09 & 5.03 & Ar II & 16.44 & 19.26 & $3 d{ }^{4} D$ & $4 p{ }^{4} \mathrm{P}^{\circ}$ \\
\hline 30 & 442.39 & 3.99 & Ar I & 11.72 & 14.52 & $4 s^{\prime}[1 / 2]$ & $5 p^{\prime}\left[\begin{array}{ll}1 & 1 / 2\end{array}\right]$ \\
\hline 31 & 447.47 & 4.77 & Ar II & 18.66 & 21.43 & $3 \mathrm{~d}^{2} \mathrm{D}$ & $4 \mathrm{p}^{\prime 2} \mathrm{P}^{\mathrm{o}}$ \\
\hline 32 & 451.07 & 3.55 & Ar I & 11.83 & 14.58 & $4 s^{\prime}[1 / 2]$ & $5 p[1 / 2]$ \\
\hline 33 & 459.60 & 3.08 & Ar I & 11.83 & 14.52 & $4 s^{\prime}[1 / 2]$ & $5 p^{\prime}\left[1 \frac{1}{2}\right]$ \\
\hline 34 & 462.84 & 3.42 & Ar I & 11.83 & 14.51 & $4 s^{\prime}[1 / 2]$ & $5 p\left[\begin{array}{ll}2 & 1 / 2\end{array}\right]$ \\
\hline 35 & 470.23 & 2.94 & Ar I & 11.83 & 14.46 & $4 s^{\prime}[1 / 2]$ & $5 p^{\prime}\left[\begin{array}{ll}1 & 1 / 2\end{array}\right]$ \\
\hline 36 & 476.86 & 3.23 & Ar I & 12.91 & 15.51 & $4 \mathrm{p}[1 / 2]$ & $6 \mathrm{~d}^{\prime}\left[\begin{array}{ll}1 & 1 / 2\end{array}\right]$ \\
\hline 37 & 483.66 & 3.28 & Ar I & 12.91 & 15.47 & $4 p[1 / 2]$ & $9 \mathrm{~s}\left[1 \frac{1}{2}\right]$ \\
\hline 38 & 487.62 & 2.83 & Ar I & 12.91 & 15.45 & $4 p[1 / 2]$ & $7 d\left[1 \frac{1}{2}\right]$ \\
\hline 39 & 492.10 & 3 & Ar I & 13.09 & 15.61 & $4 \mathrm{p}\left[2 \frac{1}{2}\right]$ & $10 \mathrm{~d}\left[3^{1 / 2}\right]$ \\
\hline 40 & 511.82 & 2.37 & Ar I & 13.09 & 15.52 & $4 p\left[\begin{array}{ll}2 & 1 / 2\end{array}\right]$ & $6 d^{\prime}\left[\begin{array}{ll}2 & 1 / 2\end{array}\right]$ \\
\hline 41 & 516.22 & 2.89 & Ar I & 12.91 & 15.31 & $4 \mathrm{p}[1 / 2]$ & $6 \mathrm{~d}[1 / 2]$ \\
\hline 42 & 518.77 & 2.91 & Ar I & 12.91 & 15.30 & $4 p[1 / 2]$ & $5 d^{\prime}\left[\begin{array}{ll}1 & 1 / 2\end{array}\right]$ \\
\hline 43 & 521.82 & 2.59 & $\mathrm{Cu} \mathrm{I}$ & 3.82 & 6.19 & $4 p^{2} \mathrm{P}^{\circ}$ & $4 d^{2} \mathrm{D}$ \\
\hline 44 & 525.27 & 3.07 & Ar I & 13.09 & 15.45 & $4 p\left[\begin{array}{ll}2 & 1 / 2\end{array}\right]$ & $7 d\left[3^{1 / 2}\right]$ \\
\hline 45 & 570.02 & 2.08 & $\mathrm{Cu} \mathrm{I}$ & 1.64 & 3.82 & $4 \mathrm{~s}^{2} 2 \mathrm{D}$ & $4 p^{2} \mathrm{P}^{o}$ \\
\hline 46 & 601.36 & 1.98 & Ar I & 13.08 & 15.14 & $4 p\left[\begin{array}{ll}2 & 1 / 2\end{array}\right]$ & $5 \mathrm{~d}[1 / 2]$ \\
\hline 47 & 617.01 & 1.92 & Ar I & 13.17 & 15.18 & $4 p\left[1 \frac{1}{2}\right]$ & $7 \mathrm{~s}\left[1 \frac{1}{2}\right]$ \\
\hline 48 & 653.81 & 2.3 & Ar I & 13.08 & 14.95 & $4 p\left[\begin{array}{ll}2 & 1 / 2\end{array}\right]$ & $4 d^{\prime}[1 / 2]$ \\
\hline 49 & 659.61 & 2.14 & Ar I & 13.08 & 14.95 & $4 p\left[\begin{array}{ll}2 & 1 / 2\end{array}\right]$ & $4 d^{\prime}[1 / 2]$ \\
\hline
\end{tabular}

CuII, and the most intense atomic spectral line was the resonant spectral lines of the copper atom with $\lambda=324.75$ and $327.39 \mathrm{~nm} \mathrm{CuI}$, in which the lower energy level is basic one. The highest upper-level energy for CuII lines was $E_{\text {up }}=18.77 \mathrm{eV}$, and for atomic lines the maximum upper-level energy was $E_{\text {up }}=7.18 \mathrm{eV}$. Bands of the second positive system of the nitrogen molecule were also observed in the UV spectrum, be- cause in these experiments the evacuation of the discharge chamber took place only up to a residual air pressure of $\approx 10 \mathrm{~Pa}$. In the wavelength range 360 $659 \mathrm{~nm}$, radiation was observed mainly at the ArI and ArII transitions, as well as the intense spectral line of the hydrogen atom $(\lambda=656.29 \mathrm{Ha})$, which is due to the residual air pressure in the chamber after its pumping by a vacuum pump. 
At a distance between the electrodes of $2 \mathrm{~mm}$ and when using a bipolar generator of high-voltage nanosecond pulses (with a strong overvoltage of the discharge gap), one or more cathode spots are formed, which move towards each other.

For a high-voltage nanosecond discharge in argon at atmospheric pressure, some optical and gas-dynamic characteristics of the cathode spot plasma were given in [7]. However, in these experiments, carried out at a distance $d=10 \mathrm{~mm}$ between aluminum electrodes, the radiation of the plasma cathode spot with a diameter of $\approx 0.2-0.3 \mathrm{~mm}$ and the bound plasma of the diffuse discharge, which occupied most of the discharge gap, was clearly recorded. The main part of the discharge energy is introduced into the cathode spot in the plasma phase, so in a scattering plasma clot, energy is first introduced into the electronic component, followed by the transfer of this energy from electrons to ions. Therefore, the mechanism of formation of excited copper ions in plasma can be determined by the processes of their excitation by electrons from the ground state of the corresponding ion. Effective cross sections of excitation of transition metal ions by electron impact are large and, for example, for zinc ions reach $10^{-16} \mathrm{~cm}^{2}$ [13]. Appropriate cross sections for copper ions are currently unknown.

A prerequisite for such processes is a high concentration of electrons in the plasma of overvoltage discharges of nanosecond duration, which reaches $10^{17} \mathrm{~cm}^{-3}$ [14]. Fig. 4 shows oscillograms of radiation at transitions of the most intense spectral (resonant) lines of copper and argon atoms from the plasma of an overvoltage nanosecond discharge at an argon pressure of $100 \mathrm{kPa}$.

Radiation at transitions of the copper atom was in the afterglow of the first maximum of the pulsed power, and weak second luminescence maxima were recorded only for the spectral lines with $\lambda=306.34$ and $521.82 \mathrm{~nm} \mathrm{CuI}$ at time $t=150 \mathrm{~ns}$. It is probable that, at atmospheric argon pressure, the duration of the diffuse stage of a high-voltage nanosecond discharge does not exceed $100 \mathrm{~ns}$, and the second luminescence maxima of the copper atom lines appear already at the contracted discharge stage. Such a picture of the development of such discharges was established in [15] during highspeed photography of the discharge with nanosecond time separation. The absence of a repeated maximum on the oscillogram of the spectral line $249.1 \mathrm{~nm} \mathrm{CuI}$, the lower level of which is the basic energy level of the copper atom, may be due to the process of selfabsorption of radiation at the channel stage of discharge, when the concentration of copper vapor in plasma increases.

The maximum values of the average power of UV radiation in argon are obtained at an argon pressure of $100 \mathrm{kPa}$ and a distance between the electrodes of $2 \mathrm{~mm}$. Thus, for different ranges of UV radiation, they were as follows: UV-C (200-280 nm) - $67 \mathrm{~mW} / \mathrm{m}^{2}$, UV-B (280$315 \mathrm{~nm})-65 \mathrm{~mW} / \mathrm{m}^{2}$ and UV-A (315-400 nm) $204 \mathrm{~mW} / \mathrm{m}^{2}$ (at $\left.U_{\mathrm{ZAR}}=20 \mathrm{kV}, f=1 \mathrm{kHz}\right)$. When the distance between the electrodes increased to $7 \mathrm{~mm}$ at an argon pressure of $100 \mathrm{kPa}$, the maximum value of the average power of UV radiation decreased (Fig. 6).

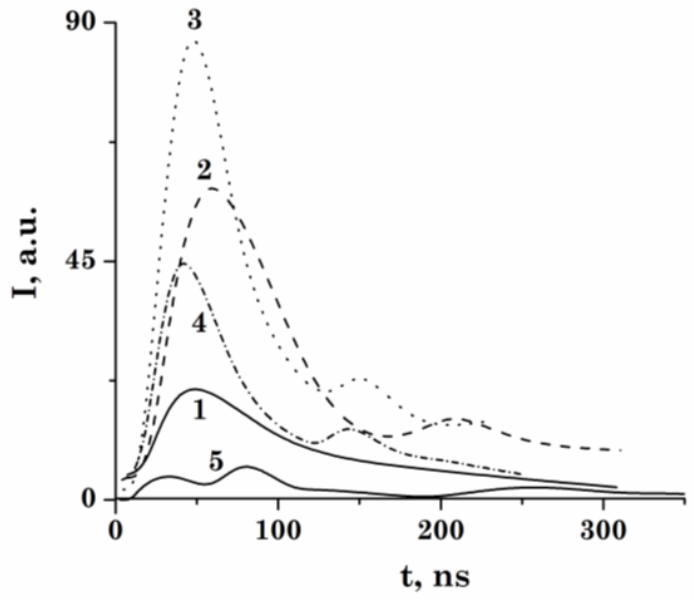

Fig. 4 - Oscillograms of luminescence at transitions of copper and argon atoms: $1-249.1 \mathrm{~nm} \mathrm{CuI}, 2-306.34 \mathrm{~nm} \mathrm{CuI}, 3-$ $470.23 \mathrm{~nm}$ ArI, $4-521.82 \mathrm{~nm} \mathrm{CuI}$ in the discharge at an argon pressure of $100 \mathrm{kPa}, 5$ - pulse power in the discharge at an argon pressure of $100 \mathrm{kPa}(d=2 \mathrm{~mm})$

Radiation at the transition of the argon atom with $\lambda=470.23 \mathrm{~nm}$ ArI was also observed in the afterglow of the first maximum of the discharge pulse power, which can be determined by the recombination mechanism of population of its upper energy level.

Fig. 5 and Fig. 6 show the results of optimization of the average power of UV radiation discharge depending on the frequency of pulses at an argon pressure of $100 \mathrm{kPa}$ and different distances between the electrodes: 2 and $7 \mathrm{~mm}$.

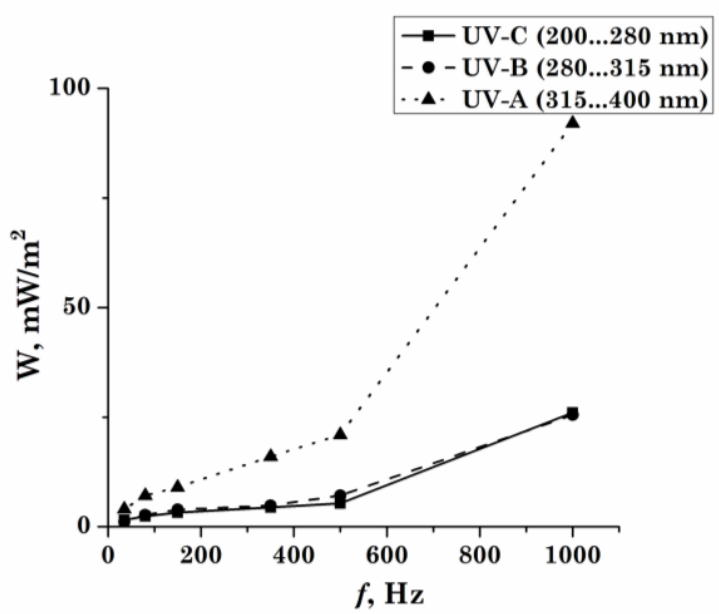

Fig. 5 - Dependence of the UV intensity - UV-C, UV-B, UV-A radiation - of high-voltage nanosecond discharge ranges on the repetition frequency of voltage pulses at a charging voltage $U=13 \mathrm{kV}(f=80 \mathrm{~Hz}, p(\mathrm{Ar})=100 \mathrm{kPa}$ and $d=2 \mathrm{~mm})$

With increasing pulse repetition frequency from 40 to $1000 \mathrm{~Hz}$ in a discharge at $p(\mathrm{Ar})=100 \mathrm{kPa}$, the largest was an increase in the intensity of discharge radiation in the UV-A range, in particular, in the frequency range $\Delta f=350-1000 \mathrm{~Hz}$, it increased from 8 to $95 \mathrm{~mW} / \mathrm{m}^{2}$. In the UV-B and UV-C ranges, an increase in the radiation power density was smaller and was observed in the range of $3.0-25.0 \mathrm{~mW} / \mathrm{m}^{2}$. 


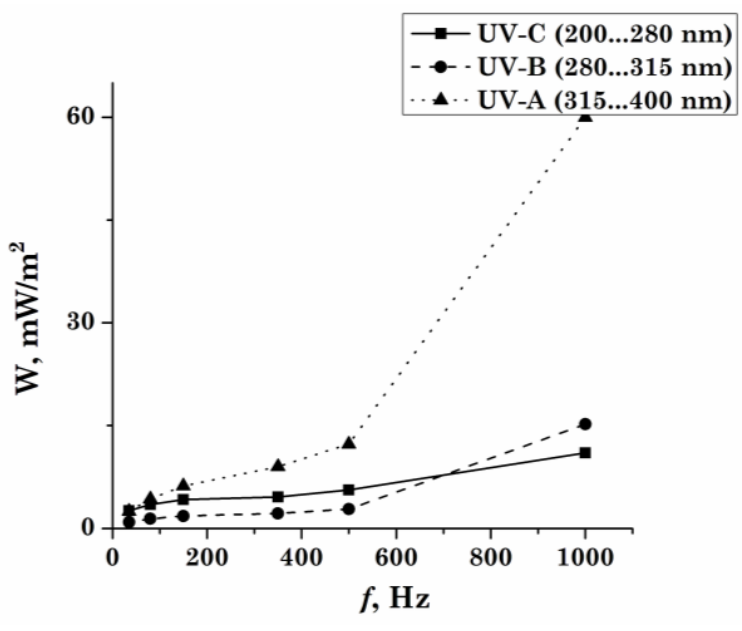

Fig. 6 - Dependence of the UV intensity - UV-C, UV-B, UV-A radiation - of high-voltage nanosecond discharge ranges on the repetition frequency of voltage pulses at a charging voltage $U=13 \mathrm{kV}(f=80 \mathrm{~Hz}, p(\mathrm{Ar})=100 \mathrm{kPa}$ and $d=7 \mathrm{~mm})$

In a discharge at $p(\mathrm{Ar})=100 \mathrm{kPa}$, an increase in the intensity of UV radiation of plasma depending on the magnitude of the charging voltage on the operating capacitor of the high-voltage modulator at a fixed repetition rate was less effective and was in the range 8.0$24 \mathrm{~mW} / \mathrm{m}^{2}$. The relative ratios between the radiation intensities in the ranges UV-C, UV-B, UV-A were the same as for the corresponding frequency dependences.

Examination of photographs of the surface of films deposited from nanosecond overvoltage high-voltage discharge plasma between copper electrodes at argon pressures of 100 and $150 \mathrm{kPa}$ showed that the film nanostructures with a diameter of 2-30 nm are deposited on the glass surface in the form of separate islands, similar to the nanostructures of copper oxides synthesized in the same discharge in air at atmospheric pressure [16]. To determine the size of nanostructures, a gel based on standard nanostructures of spherical gold with a diameter of $20 \mathrm{~nm}$ was applied to the film surface. Comparative analysis of the sizes of spherical nanostructures of gold and deposited nanostructures of copper allowed to establish their diameter.

The transmission spectrum of a thin copper film in the visible part of the wavelengths is shown in Fig. 7. The study of film transmission was performed in the middle of the substrate radius. It was established that the films are quite inhomogeneous in radius, which is mainly due to gas-dynamic phenomena within the discharge gap and the use of a point source of steam of the electrode material.

Narrow bands of illumination of the film in the blue part of the spectrum (at wavelengths of 420 and $450 \mathrm{~nm}$ )

\section{REFERENCES}

1. G.A. Mesyats, Usp. Fizich. Nauk. 165 No 6, 601 (1995).

2. O.K. Shuaibov, O.Y. Minya, M.P. Chuchman, A.O. Malinina, O.M. Malinin, V.V. Danilo, Z.T. Gomoki, Ukr. J. Phys. 63 No 9, 790 (2018).

3. O.K. Shuaibov, A.O. Malinina, O.M. Malinin, Novi gazorozryadni metody oderzhannya selektyunogo ultrafioletovogo $i$ vydymogo vyprominyuvannya ta syntezu nanostruktur oksy`div perexidnyx metaliv. (Uzhgorod : are most likely due to the action of UV radiation of the discharge plasma in the spectral range $200-230 \mathrm{~nm}$ on the film, which in the process of depositing the film leads to radiation defects copper-based films.

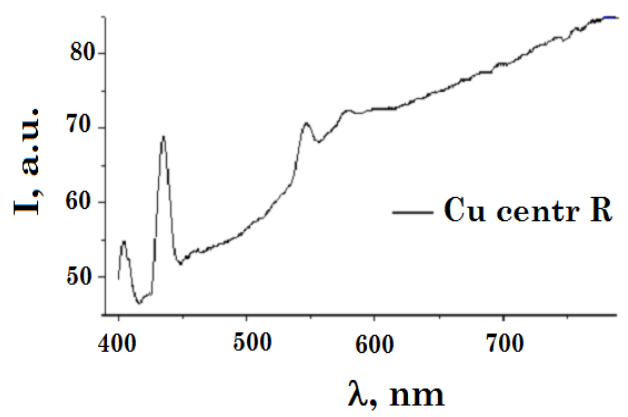

Fig. 7 - The transmission spectrum of a thin film of copper during the localization of the spectrometer in the middle of the radius of the substrate

\section{CONCLUSIONS}

Thus, it was found that at argon pressures of 100 and $150 \mathrm{kPa}$ between copper electrodes at an interelectrode distance of $2 \mathrm{~mm}$, a fairly homogeneous in space overvoltage nanosecond discharge with a pulsed electric power up to $3.8 \mathrm{MW}$ was ignited, and the energy contribution to the plasma per pulse reached $470 \mathrm{~mJ}$.

The study of the spectral characteristics of plasma based on copper-argon vapor-gas mixtures showed that the most intense were the spectral resonance lines of the copper atom $(\lambda=324.75$ and $327.39 \mathrm{~nm} \mathrm{CuI})$; of the single-charged copper ion lines in the range of 200$330 \mathrm{~nm}$, the line $\lambda=227.62 \mathrm{~nm}$ CuII was the most intense. From ionic spectral lines in the visible part of the spectrum, a line with $\lambda=618.86 \mathrm{~nm}$ CuII was isolated. Automatic irradiation of the substrate and film nuclei on the substrate with hard UV radiation of copper atoms and ions from the discharge plasma is promising for the impact on the electrical [17] and optical characteristics (formation of enlightenment bands) of the synthesized copper films.

The maximum value of the average power of UV radiation was obtained at $p(\mathrm{Ar})=100 \mathrm{kPa}$ and the distance between the electrodes of $2 \mathrm{~mm}$ for the UV-A range, and the absolute radiation densities in different UV ranges reached: UV-C - $67 \mathrm{~mW} / \mathrm{m}^{2}$, UV-B $65 \mathrm{~mW} / \mathrm{m}^{2}$ and UV-A $-204 \mathrm{~mW} / \mathrm{m}^{2}$ (at $U \mathrm{ZAR}=20 \mathrm{kV}$, $f=1 \mathrm{kHz}$ ), for the discharge at $p(\mathrm{Ar})=6.7 \mathrm{kPa}$ the radiation power decreased more than an order of magnitude. The most effective was to increase the pulse repetition frequency to $1000 \mathrm{~Hz}$, rather than increase the charging voltage on the operating capacitor of the highvoltage modulator.
UzhNU «Goverla»: 2019). [In Ukrainian].

4. A.K. Shuaibov, A.I. Minya, A.A. Malinina, R.V. Gritsak, A.N. Malinin, Ukr. J. Phys. 65 No 5, 400 (2020).

5. V.V. Ivanov, A.A. Efimov, D.A. Myilnikov, A.A. Lizunova, A.V. Bogazeev, I.V. Beketov, S.V. Scherbinin, Tech. Phys. Lett. 42, 876 (2016).

6. O.A. Omarov, V.S. Kurbanismailov, G.B. Ragimhanov, M.H. Gadzhiev, M.V. Kurbanismailov, Vestnik Dagestanskogo 
universiteta 6, 5 (2012).

7. V.S. Kurbanismailov, O.A. Omarov, G.B. Ragimhanov, Appl. Phys. 2 No 3, 35 (2014).

8. N.G. Vnukova, A.L. Kolonenko, V.A. Lopatin, G.N. Churilov, J. Siberian Federal University. Chem. 2 No 4, 148 (2011).

9. V.S. Kurbanismailov, O.A. Omarov, G.B. Ragimhanov, D.V. Tereshonok, Techn. Phys. Lett. 45, 4 (2019).

10. Runaway electrons preionized diffuse discharge (Ed. by V.F. Tarasenko) (New York: Nova Science Publishers Inc.: 2014).

11. A.R. Striganov, Tablitsyi spektralnyih liniy neytralnyih $i$ ionizirovannyih atomov (M.: Atomizdat: 1966). [In Russian].
12. NIST Atomic Spectra Database Lines Form https:// physics.nist.gov/ PhysRefData/ ASD /lines_form.html

13. A.N. Gomonai, J. Appl. Spectrosc. 82 No 1, 13 (2015).

14. D. Levko, L.L. Raja, Phys. Plasmas 22, 123518 (2016).

15. D.V. Beloplotov, V.I. Lomaev, D.A. Sorokin, V.F. Tarasenko, J. Phys.: Conf. Series 652, 012012 (2015).

16. A.K. Shuaibov, A.Y. Minya, A.A. Malinina, A.N. Malinin, V.V. Danilo, M.Yu.Sichka, I.V. Shevera, Am. J. Mech. Mater. Eng. 2 No 1, 8 (2018).

17. A.H. Abduev, A.Sh. Asvarov, A.K. Ahmetov, R.M. Emirov, V.V. Belyaev, Tech. Phys. Lett. 43, 1016 (2017).

\title{
Дослідження умов осадження тонких плівок міді з продуктів деструкції електродів перенапруженого високовольтного розряду в аргоні високого тиску
}

\author{
О.К. Шуаібов ${ }^{1}$, О.Й. Миня ${ }^{1}$, В.І. Чигінь ${ }^{2}$ Р.В. Грицак ${ }^{1}$, А.О. Малініна ${ }^{1}$, М.I. Ватрала ${ }^{1}$, 3.T. Гомокі $^{1}$
}

1 ДВНЗ «Ужгородський національний університет», Народна площа, 3, 88000 Ужгород, Украӥна

2 Національний університет "Львівська політехніка», вул. С. Бандери, 12, 79013 Львів, Україна

Приведено характеристики високовольтного наносекундного розряду між мідними електродами в аргоні при тисках 100-150 кПа. В процесі мікровибухів неоднорідностей на робочих поверхнях електродів в сильному електричному полі у розрядний проміжок вносились пари міді за рахунок утворення ектонів. Це створювало передумови для синтезу тонких наноструктурованих плівок міді ультрадисперсного порошку міді. Плівки міді осаджувались на діелектричній підкладщі, що була встановлена поблизу системи електродів. Досліджено просторові і електричні характеристики високовольтного наносекундного розряду при віддалі між електродами $d=2$ мм. Проведено вивчення спектрів випромінювання розряду і осцилограм випромінювання найбільш інтенсивних спектральних ліній та смуг, що дозволило встановити основні збуджені продукти, які утворювались в плазмі. Наведено результати оптимізації інтенсивності УФ-випромінювання розряду в залежності від частоти, величини зарядної напруги і міжелектродної віддалі. Проведена оптимізація усередненого за часом УФ-випромінювання точкового випромінювача в залежності від напруги живлення високовольтного модулятора i частоти слідування розрядних імпульсів. Досліджено спектри пропускання світла синтезованими в експерименті тонкими плівками міді.

Ключові слова: Високовольтний наносекундний розряд, Мідь, Плазма, УФ-випромінювання. 